\title{
Surveying the Impact Quality of the Bank's electronic Services on Financial Performance (with the Emphasis on the Customer Satisfaction Model)
}

\author{
M.A. Ali Panjomi Mohmoodi ${ }^{1}$ \\ M.A. Asmail Kholafazade Asetmal ${ }^{2}$
}

\begin{abstract}
:
Survival of any organization in today's competitive environment, is based on clients. Every organization and its customers' current and future needs are identified and satisfied by providing to meet those needs, and it continues to be applied in order to increase their satisfaction. Many organizations utmost sense of audience satisfaction and value creation institute in their strategic plans, mission statements and policy organizations are planning accordingly. The aim of this study was to investigate the impact of e-banking service quality, customer satisfaction and financial performance of banks.

This investigation is inspired by the idea of Long-Linked Technology of James Thompson, in an environment of uncertainty factors (the research model). This study was to investigate the effect of customer perceived e-service quality on bank financial performance and to test the mediating role of customer satisfaction on customer perception of service quality of financial performance of e-banking.

The results of the field study analyzing the effects of e-service quality and customer satisfaction on financial performance of public and private banks have been gathered. The outcome of the analysis showed that the quality of the electronic components of the ATM quality of service, phone banking, internet banking quality, has a positive impact on customer satisfaction.

The results showed that the effect of customer satisfaction due to the quality of e-banking services has a mediating role on the overall financial performance.
\end{abstract}

Key Words: e-banking, customer satisfaction, performance, management.

\section{Introduction}

Nowadays, several attempts by scholars, experts and managers of business is done to improve performance of management. Customer satisfaction performance and its indicators shows that this is one of the most important determinants of success in organizations.

But before that, focuses on attracting new customers, the policy of the organization, the current policy of strategic and commercial corporations. Maintaining and improving customer loyalty and trust are central to the organization. Feature of the present century

${ }^{1}$ M.A.Department of Management, Tabriz Branch, Tabriz University, Tabriz Iran ${ }^{2}$.correspond author. M.A: Department of Management, Mahabad Branch, Islamic Azad University, Mahabad, Iran. 
is the miraculous technological development Community information and using it to improve the speed and quality of service. This development also affected the banking industry, causing the major changes that the industry ever had. This progress in the banking industry has caused significant changes in the entire economical and financial relations.

Rapid advances in the Information Technology industry, causes large changes in the forms of cash, money transfer systems, service delivery and also customer satisfaction in the banking sector. These changes have affected the financial performance of banks.

On the one hand, using the techniques of e-banking, the simplification of tasks and lower costs has increased the number of customers and thereby increased the level of management.

\section{Statement of the problem}

Like other industries, in the banking industry, the purpose of a marketing plan is that customers can identify market needs, and services to the market, thereby increasing the value of customers being able to satisfy them. Various forms of e-banking services to customers by providing special equipment which can include branches based banking, electronic banking terminals based on sales, internet banking, banking-based fax, phone banking, ATM banking systems are based on the .

In most of the literature relating to banking technology is expressed preferences and perceived customer service quality, significant effect on the success of the bank. Market analysis based on customer needs; develop a system of services that consider the client's needs, taking into account the quality of service, including issues that this area is known.

\section{Background research:}

Customer satisfaction is one of the fundamental goals of modern service firms (Jones and Sasser, 1995). This is to improve profitability through advertising, face to face and reduces advertising costs, will improve financial performance. (Reichheld1996; Yeung et al. 2002) Many studies of the relationship between customer satisfaction and financial performance have been approved, of which the following can be noted. (Wiele et al., 2002; Yeung et al., 2002; Anderson et al., 1994) (Ashiqullah, 2010)

"Syed Mahmoud Ashiqllah" (2010) in a study entitled "Relationship between quality auto service, customer satisfaction and financial performance of banks across Asia" examines the interaction of the three variables of e-service quality, customer satisfaction and financial performance is discussed. The main hypothesis of this study was:

1 - Automatic Quality of Service (ATM, phone banking, internet banking and special services) is associated with financial performance.

2 - Financial functionally linked with customer satisfaction.

The results showed that the electronic service quality (ATM .435, Telephone Banking .434, Internet banking .349 and .645 services are associated with financial performance. The results indicated that customer satisfaction is a factor of .597 at a significance level of less than .01 is associated with financial performance. 
Another study in 2009 by researchers named "Alessandro Bruno Arbor and Bruno Busacca" theme customer satisfaction in banking services as "customer satisfaction or non-satisfaction in retail banking: the effects of asymmetric functional features" that should have been done in Italy it is not empty of useful tips. This study examines the following aspects of customer satisfaction drivers. Functional quality (reliability, accuracy, security, speed), relationship quality (responsiveness, assurance, communication), facilities (24 hour service, Parking, ATMs), economic (interest rates, reasonable price, good quality price rate), tangibles (Bank of the physical space, decoration) and problem solving (how the complaints, the ability to avoid conflict)

The main hypothesis of this study is the fact that the functional aspects of customer satisfaction in retail banking nonlinear effects are significant. The results show that the performance of listed banks in. 60, changes in variable explain customer satisfaction.

"Gregory R. Heim and M. George. Fields" in 2007 in the United States have to do another study. The results showed that .89 of overall satisfaction and .94 of customer loyalty is explained by perceived e-service quality.

Despite the fact that e-banking in Iran has been raised in recent decades, some experimental studies in with significant results have been carried out . For example, we can mention the following research:

"The effects of electronic banking on the profitability of commercial banks" (Goodarzi and Zybdy, 2008), In this study, the results of measures taken by the country's commercial banks for the expansion of electronic banking and its effect on their profitability, is investigated in the form of an econometric model.

The model used in this study based on the theory of constructivism (SCP) and the return on total assets (ROA) as the dependent variable; Index of market concentration, bank size, number of every bank teller machines (ATM) and a dummy variable to joining Bank grab networks are defined as independent variables.

The results showed that an increase in the number of ATM machines in banks, had a positive impact on profitability. The Effect of net momentum has increased after joining the bank. Accordingly, we conclude that the development of electronic banking, has a significant positive effect on the profitability of commercial banks.

Another recent research in this field is titled "Developing and developed a model for measuring customer satisfaction in the banking industry and measuring customer satisfaction bank on it" (Dyvandr\&dlkhvah, 2005), this study sought to identify the characteristics of some new measures of customers satisfaction. In this study, questionnaires were used to collect data.

This study, designed from a theoretical model, compared all indexes of the field conducted by other researchers and international experts of the banking systems. 5 main indicators were adopted to measure customer satisfaction. Main criteria for the study include the quality of services, cost of obtaining services, access to services, property services and management of customer complaints. Results of research hypotheses stated as is the satisfaction of our customers all the main five research are high. It is worth noting that the lowest customer satisfaction index was represented by the quality of services and the cost of obtaining services.

Also another study entitled "Perceptions of price and quality of private and public customers in behavioral decision" (Hamdi, H. 2008) has been conducted in this area. 
This study has attempted to influence customers' perceptions of price and quality in behavioral decision be reviewed. 8 hypotheses proposed in this study the relationship between price, quality, customer satisfaction, customer behavior and decisions of expected value are studied.

The results showed that the price perceptions and the expected value of the customer perception of quality and customer satisfaction, the expected value of the customer and customer satisfaction, and customer satisfaction and customer behavioral decisions and most importantly the relationship between perceived price and customer decisions there is a direct, yet perceptions of perceptions of price, the more light will be on behavioral decisions.

\section{Research model}

After a review of the field literature discussed above, such as customer satisfaction with e-service quality variables were selected on the Bank's financial performance. This variables include e-service quality (quality of automated teller machines, telephone banking, internet banking services, especially the price) is considered as an independent variable in the study. Banks and financial performance is the dependent variable of the study and Customer satisfaction with service quality and customer satisfaction has a mediating role. According to this explanation, the model is shown below.

Figure 1-1: a conceptual framework for research

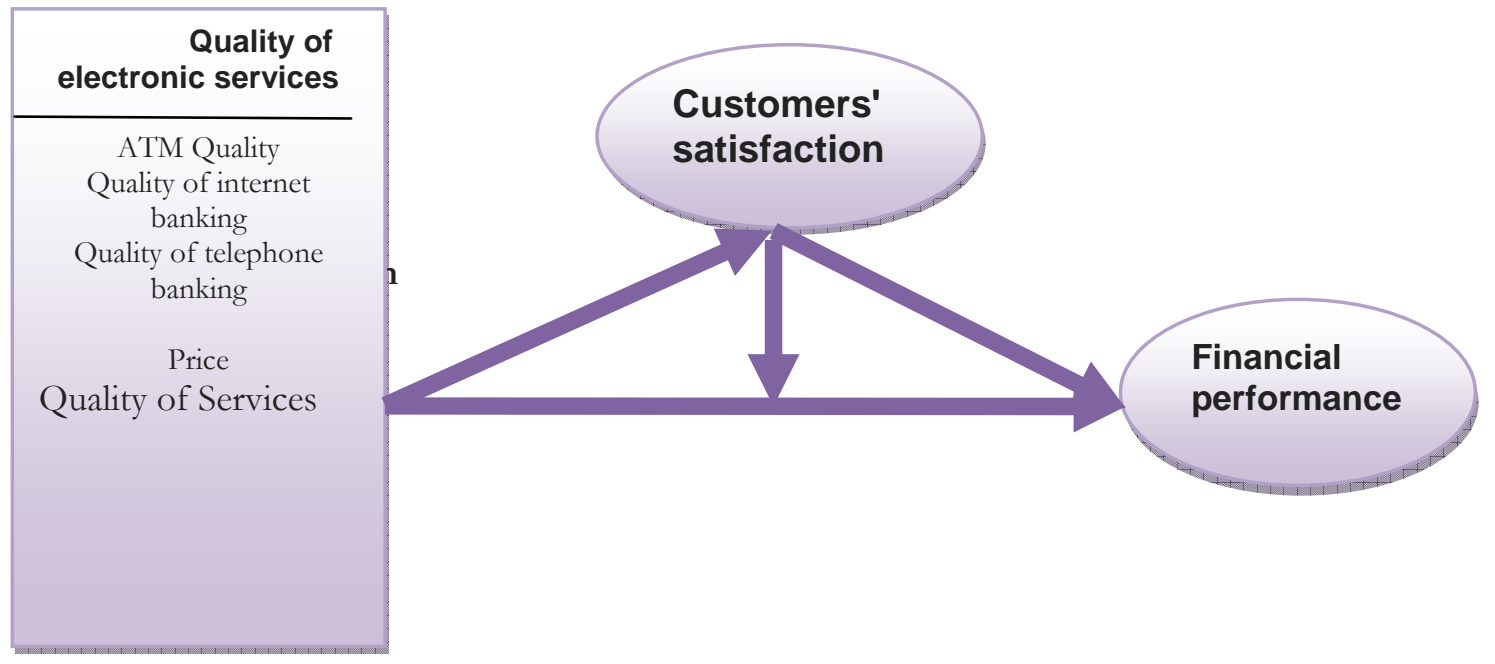

This investigation is done in banks. On the other hand, due to the specialized nature of the subject and the need for accurate and complete information, not only the bank, but also its customers are considered as part of the target population. The study 
sample has been selected from various customers of national banks, that organize their activities in the area of East Azarbaijan province.

Because of the qualitative variables, the number of the appropriate sample size for infinite population, in order ensure the correctness of the findings, the Cochrane formula is used in the following conditions:

Formula 1-3: Cochran

$\mathrm{n}=\frac{\mathrm{z}\left(\frac{\alpha}{2}\right)^{2} \mathrm{p}(1-\mathrm{p})}{\varepsilon^{2}}$

$\mathrm{n}=$ number of samples analyzed

$\varepsilon=\operatorname{accuracy}(5 \%)$

$\mathrm{P}=$ percentage of response homogeneity $(50 \%)$

$\mathrm{Z}=$ the normal distribution at a confidence level of $\alpha-1(96 / 1)$

Significance $\alpha=$ percent $(5 \%)$

By substituting these values in the formula we have:

$$
n=\frac{(1 / 96)^{2} \times \% 50 \times \% 50}{\% 5^{2}}=384 / 16 \cong 384
$$

According to the above calculations, the sample size for the study was 384 .

According to this study, the variables in the basic data needed to test the hypothesis of a questionnaire, and secondary data from the banks documentation and library information is collected. Audience questionnaire will be taken for every single customer.

\section{Hypothesis}

According to the literature review and research hypotheses based on the following objectives are formulated.

1 - Improving the quality of electronic services will improve customers' satisfaction.

2 - Quality of electronic services will improve the financial performance of banks.

3 - The impact of customer satisfaction on financial performance of e-banking service quality has a mediating role.

\subsection{Reliability and Validity Assessment Tool}

Data collected in this study to determine the validity of face validity (symbol) was used.

To this end, first initial questionnaire was prepared and placed in the hands of faculty experts to comment on the accuracy of their design, which offers them with minor changes in question, occurred.

To estimate the reliability of the questionnaire on a pilot sample of 30 people, the Cornbrash's Alpha was used. The following shows the first and second questions are highly correlated to each other are the high reliability of the questionnaire. 
Table 1-1 Cornbrash's alpha coefficients for each variable

\begin{tabular}{|r|r|}
\hline Variables & The coefficientalpha \\
\hline Quality of electronic services & .863 \\
\hline Customer satisfaction & .619 \\
\hline
\end{tabular}

Table 1-2 Cornbrash's alpha coefficients for total questionnaire

\begin{tabular}{|r|r|}
\hline Numbers question & Cornbrash's alpha \\
\hline 28 & .89 \\
\hline
\end{tabular}

\section{Hypothesis testing:}

Data in the study at three levels: 1) Univariate analysis, 2) a bivariate analysis, and3) multivariate analysis is performed. In the first part of the individual variables are examined, and the relationships between the mare considered. The indices of central tendency, dispersion and deviation from symmetry is calculated from the overall image of the sample is obtained. Thenthebivariateanalysis, therelativerankofavaluetypevariablethatisusedSpearman'srank correlation test. Finally, the third part of the four-stage multivariate regression analysis using EViews 6 software is used.

\subsubsection{Electronic Service Quality}

Electronic service quality as independent variable in this study was original. The eservice quality factors, such as the quality of the research, ATM, telephone banking, internet banking, and the price of services is defined. According to the results of quality electronic services to banks, having lots of moderate to moderately incline located.In addition to this, the absolute value of skewness, which is less than 0.5 , is the test results: Due to the high level and low level Sig, the null hypothesis of equal means of electronic service quality with the $47 / 3$ times the average of the amount of the claim cannot be denied and cannot be rejected. In other words, it can be stated that the average quality of electronic services for a population equivalent of $47 / 3$ is.

\subsubsection{Customer Satisfaction}

In this survey of customer satisfaction based on overall customer satisfaction with the services of employees, as well as physical satisfaction, satisfaction, satisfaction with the process service fees and studied. It can be argued that the results of the descriptive statistics of the Bank of satisfied customers, moderate to relatively high there. According to statistics, the absolute deviation from the symmetry of the data, with customer satisfaction and normal distributions are symmetric(the absolute value of Skewness is less than $5 / 0$ is nearly zero). 
One-Sample Test Results shows the upper and lower limits of the Sig, the null hypothesis of equality of mean customer satisfactionwith51/3cannot be denied, and the average of the claim, the amount cannot be rejected.

\subsubsection{Financial Performance}

In this study to measure the financial performance of ROA and market share of deposits and granting loans consists of two components, was used. In Table 1, the valuesof these measures for banks and descriptive statistics of the amount of central tendency and dispersion statistics are presented.

Table1: Financial performance data

\begin{tabular}{|c|c|c|c|c|c|}
\hline Row & Bank & $\begin{array}{l}\text { Financial } \\
\text { Performance }\end{array}$ & $\begin{array}{c}\text { Lending } \\
\text { facility }\end{array}$ & Deposits & Rate of return on asset \\
\hline 1 & Mele & $12 / 61$ & $13 / 17$ & $18 / 46$ & $6 / 2$ \\
\hline 2 & Saderat & $13 / 54$ & $18 / 85$ & $14 / 88$ & $6 / 9$ \\
\hline 3 & Melat & $13 / 46$ & $16 / 75$ & $16 / 84$ & $6 / 8$ \\
\hline 4 & Refah & $4 / 87$ & $4 / 47$ & $2 / 96$ & $7 / 2$ \\
\hline 5 & Saman & $5 / 57$ & $3 / 23$ & $3 / 4$ & $10 / 1$ \\
\hline 6 & Parseyan & $4 / 97$ & $/ 93$ & $3 / 3$ & $10 / 7$ \\
\hline & Mean & $9 / 14$ & $9 / 47$ & $9 / 97$ & $7 / 98$ \\
\hline & SD & $4 / 04$ & $6 / 92$ & $6 / 87$ & $1 / 75$ \\
\hline
\end{tabular}

The One-Sample Test results are presented in Table 1, shows the amount Sig, the null hypothesis of equality of mean financial performance with the 9.14 times the average of the amount of the claim cannot be denied and cannot be rejected. In other words, it can be stated that the average financial performance for the equivalent of 9.14 is.

\subsection{Bivariate analyzes}

We analyze the characteristics of the study population. Now we will analyze the relationships between pairs of variables. Given that, the independent variable and medium scale study, ordinal, and scale value of the dependent variable is a proportion, the Spearman correlation coefficient was used to analyze their relationships.

\subsubsection{Service quality of e-banking}


Correlation analysis, a statistical tool for assessing the degree of relationship between two variables, the correlation between the severity and type of relationship (direct or inverse) shows, Coefficient between 1 and -1 and in the absence of a relationship between two variables is equal to zero.

Electronic service quality, customer perception of the quality of ATM quality performance, quality, phone banking, internet banking quality, and price and service quality is defined. Electronic service quality, customer satisfaction and financial performance in relation to the significance level of $0 / 01$ confirmed and characterized. Significance level of 0.01 e-service quality, customer satisfaction and financial performance is positively related to average. In other words, one can say with $99 \%$ in the study population, with high e-service quality, customer satisfaction and financial performance are more mobile.

\subsubsection{Customer satisfaction and financial performance}

Customer satisfaction as a mediating variable in the process impact of e-service quality on financial performance is effective. The results showed a correlation coefficient of .873 Sig amount equal to 0.000 for the relationship between customer satisfaction and financial performance, these figures indicate a strong positive correlation significant at 0.05 between these two variables. Therefore, as stated in a high level of customer satisfaction will lead to increased financial performance.

8.2.3 Multivariate analyzes

Once accepted research model, the estimated coefficient for each independent variable set, and then its effect on the dependent variable(financial performance) willbe examined.

With According to the level significance for, in above table is characterized by: «variable independent with mediating agent $\mathrm{O}$, customer satisfaction in the meaningful level0.05, boasts positive impact a significant and on financial performance is the». To Phrase catalog others, with the attention to coefficients been calculated with the increase one unit invariable, service quality electronics with mediating agentO, customer satisfaction to the amount 1.24 unit on financial performance be increasing.

\section{Test results hypothesis}

In this study, we sought to determine the effect of explanatory variables on financial performance. After that, the research hypotheses are tested using regression analyses. Table 2 shows the Results of the research hypotheses to prove each of the tests performed during the multivariate analysis.

Table2: The results of the research hypotheses

\begin{tabular}{|l|l|l|l|}
\hline Row & Hypotheses & $\begin{array}{l}\text { Type } \\
\text { of test }\end{array}$ & Result \\
\hline 1 & Quality of electronic services will improve customer satisfaction. & $\begin{array}{l}\text { The test } \\
\text { statistic F }\end{array}$ & Rejection \\
\hline 2 & Electronic services will improve the quality of banks' financial performance. & The test & Rejection \\
\hline
\end{tabular}




\begin{tabular}{|l|l|r|l|}
\hline 3 & $\begin{array}{l}\text { The impact of e-service quality, customer satisfaction has a mediating role in the } \\
\text { bank's financial performance. }\end{array}$ & $\begin{array}{r}\text { The test } \\
\text { statistic F }\end{array}$ & Rejection \\
\hline
\end{tabular}

Important findings of research

The main findings of the study based on univariate analysis, bivariate analyzes and multivariate analyzes were carried out in four chapters include:

1. Electronic service quality in banks surveyed medium and medium high.

2. Satisfaction survey created by banks is moderate to moderately high.

3. The average rate of return on assets, deposits and loans granted by the Bank of respectively 7.98 percent, $9.97 \%$ and 9.47 percent. Thee-service quality, customer satisfaction and financial performance, there is a positive correlation between averages.

4. The results indicate a strong and positive relationship between customer satisfaction and financial performance.

5. Multivariate analysis revealed thatapproximately $40 \%$ of the change in customer satisfaction, service quality electronics can be explained by the changes.

6. The results showed that about $40 \%$ of the changes in the financial performance of banks under study are explained by changes in e-service quality.

\section{Analysis of the results and conclusions}

In this section the results of the research analyzed in this research are discussed. Hypothesis 1) E-service quality has an impact on customer satisfaction.

As the first step of the regression model (based on the statistic F) is confirmed. To the above hypothesis can be expressed this way: With0.95E-service quality has an impact on customer satisfaction. The issues raisedbythisapproachandfindings"HalvlandJuanMishanJohnStewart”(2004) and "Mohammed Alhvary and Tony Ward"(2006) are consistent.

The analysis of the results obtained, it can be said to customers today expect to do one of the key components of consent is perceived. The analysis result can argue that today's customers expect to get things done on time and the consent of the most important components of perceived. Given that the electronic services provided, and the amount of time waiting for things to decrease, this could be one of the factors that attract and increase customer satisfaction. In addition to this, factors such as the affairs and finances of the home cost of material and spiritual(mind the absence of the external environment), new activities and satisfactions of being a new experience to be business leads and increase customer satisfaction.

Hypothesis 2) E-service quality has an impact on the financial performance of banks. Approval of the model in the first stage regression F-statistic based on the aboveassumptioncanbeexpressedas $95 / 0$ confidence in e-service quality has an impact on the financial performance of banks. The issues raised by this approach and findings Fvrtl 
Goudarzi, Zybdy(2008) and John Stuart Mishan(2004) and also consistent with the findings of M.Alhvary and Tony Ward(2006) is not consistent.

In relation to financial performance and its influencing factors has been a lot of research. In this regard, one of the identified factors related to innovation. Given that e-service, a new arena in the banking industry of Iran, Perhaps the novelty of e-services, most of its impact on financial performance, he said.

On the other hand, the issue of recognition of the bank, the bank increased interaction with customers through telephone banking, ATMs and the Internet can attract potential clients or virtual market, the impact of electronic services for the financial performance, he said.

The rise of e-service quality, customer satisfaction, and create a positive mindset towards the bank can attract potential customers and earn revenue from these channels effectively and improve financial performance.

Hypothesis 3) E-service quality, customer satisfaction impacts the financial performance of the bank's intermediary role.

The test statistic for this variable in the regression analysis is equal to 1.24, the fourth step in the regression model was significant at 0.05 is verifiable, the impact of e-service quality, customer satisfaction and improved financial performance of banks. This finding what cycle approach to customer service quality, customer satisfaction and quality and benefits of ethnic Saffari Halvl Mishan and research by John Stewart (2004) and the findings Muhammad Alhvary and Tony Ward (2007) suggests is aligned.

Perhaps this is the result of the improved financial performance of banks is a service that is customer satisfaction. No one in no doubt that a satisfied customer is a repeat of their interactions can be considered as the most important source of income for an institution. A satisfied customer can also increase the frequency of their interactions, and by recruiting others into the institution, and to acquaint them with the institution, the institution of financial performance of impact on society.

\section{Research proposals}

The results of the explanatory variables of electronic service quality and customer satisfaction in banks' financial performance is discussed.

In this section, the results obtained in the three sectors are analyzed, in connection with the issue, we will try to provide practical suggestions dedicated to the banking sector:

- Increase the number and the proper functioning of ATMs by banks.

- Create appropriate tools, by the banks, for online transactions and advertising programs to promote public confidence in this type of interaction.

- implement appropriate programs in order to achieve and increase customer satisfaction.

- More investments to improve the quality of electronic services. 
- Establish appropriate infrastructure and platforms to improve the quality of egovernment services.

- Improve Legislation and regulations related to electronic services.

- Deliver information and services related to the security of e-banking .

\section{References:}

Aldlaigan, A. and Buttle, A. (2002), "SYSTRA-SQ: a new measure of banks service quality", International Journal of Service Industry Management.

Alessandro Arbore \& Bruno Busacca. (2009) "Customer satisfaction and dissatisfaction in retail banking: Exploring the asymmetric impact of attribute performances" Journal of Retailing and Consumer Services 16.

Al-Hawari, Mohammed and Ward, Tony.(2006). " The effect of automated service quality on Australian banks' financial performance and the mediating role of customer satisfaction.

AlvanS...M. and Gable, AS. 2001, administrative and social terms, bottlenecks and the solution Tehran, Journal of Management Development, No. 10, pp. 19-9.

Alvani, SM. 2001, New Horizons of Public Administration Tehran, Public Administration Quarterly.No. 50.

Bahia Kamilia\&NantelJacques(2000) "A reliable and valid measurement scale for the perceived service quality of banks", International Journal of Bank Marketing.

Buttle, Francis (1996) "SERVQUAL: review, critique, research agenda", European Journal of Marketing.

Dirt, G., 1999, Research Methods in Management, Tehran, Tehran University Business School Press.249 p.

Dslr, Gary, 1994. Fundamentals of Human Resource Management.Second edition, translated by Ali Persians and Arabs, Tehran, publishing and cultural studies.P 145.

Eslami, AR. 1993. Management theories. Tehran, Mahan published. Page 356.

Faqih, and intelligent person Abul Hassan, 1980, Bureaucracy and Development in India (a historical perspective - adaptive) in Tehran. The publication.Page 62.

Favorite Band, A. 2003. General Manager, Tehran. Psychology Press, pp. 157-121.

FeghhiFarahmand, Nasser 2001, Executive Leadership Process, Islamic Azad University, Tabriz Branch, Iran, pp 2-23. FeghhiFarahmand, Nasser 2003, Permanent Leadership of Organization, First edition, Frouzesh Publication, Tabriz, Iran, pp19-32.

FeghhiFarahmand, Nasser 2003, Strategic Structure of Organization Leadership Process, Fourth edition, Islamic Azad University, Tabriz Branch, Iran, pp 10-15.

FeghhiFarahmand, Nasser 2005, Strategic Leadership of Organization, First edition, Frouzesh Publication, Tabriz, Iran, pp 19-104.

FeghhiFarahmand, Nasser 2009, Organization Strategic Plan compilation, First edition, Frouzesh Publication, Tabriz, Iran, pp 19-21.

Feghhifarahmand, Nasser 2011, Active and Dynamic Leadership of Organization, Second edition, Frouzesh Publication, Tabriz, Iran, pp 87-292.

FeghhiFarahmand, Nasser 2011a, Technology Leadership of Organization, Second edition, Frouzesh Publication, Tabriz, Iran, pp 11-18.

Gregory R. Heim And Joy M. Field.(2007)," Process drivers of e-service quality: Analysis of data from an online rating site" Journal of Operations Management. 
Jamal A., Naser, K., (2002);" Customer satisfaction and retail banking: an assessment of some of the key antecedents of customer satisfaction in retail banking", European Journal of Marketing.

JcParadi And A Ghazarian-rock.(1998), " A Framework to Evaluate Video Banking Kiosks" Elsevier Science.

Lalita A. Manrai, Ajay K. Manrai.(2007) "A field study of customers' switching behavior for bank services" Journal of Retailing and Consumer Services 14.

Parasuraman, A., Zeithaml, V.A. and Berry, L.L.(1985) "A conceptual model of service quality and its implications for future research", Journal of Marketing.

Parasuraman, A., Zeithaml, V.A. and Berry, L.L.(1988) "SERVQUAL: a multiple item scale for measuring consumer perception of service quality", Journal of Retailing.

Saburi, M. 2006. Sociology of Organizations - modern bureaucracy in Tehran, Iran. Word Press.P 170.

Samari, A., and R. M., b 0.2007, increase motivation variables affecting the progress and success of cooperative managers, Tehran, Public Administration, 50, pp. 33-1.

Sheikh, GH, 2008, The role of cooperatives in economic, social and cultural development in Iran, Journal of Cooperative No. 186.

Soil, G. (2005), writing a thesis on the research approach, Tehran, publisher reflection printing.

Stephen, P. Robbins .1999, Principles of Organizational Behavior. Tehran, Persians and Arabs translated Tehran, Office of Cultural Studies, and pp. 84-44.

Ziqi Liao and Michael Tow Cheung(2002), " Internet-based e-banking and consumer attitudes: an empirical study" Information \& Management. 